\title{
The Role of the Web Site as a Relationship Building Tool in Polish Non-profit Organizations
}

\author{
Marian Olinski, Piotr Szamrowski
}

University of Warmia and Mazury in Olsztyn

No.2 Oczapowskiego Street, 10-950 Olsztyn; Poland

E-mail.olinski@uwm.edu.pl,piotr.szamrowski@uwm.edu.pl

cross $^{\text {ref }}$ http://dx.doi.org/10.5755/j01.ee.29.3.18053

\begin{abstract}
Dialogic communication, which derives from a two-way symmetrical communication model, is considered to be an important foundation for long-lasting positive relationships with organizations and the public. The purpose of the current study was to examine the largest Polish Public Benefit Organization Web sites to determine the extent to which they use dialogic communication rules in relationship building. Also, the relation between the Web site dialogic potential and the amount of organizational revenue was scrutinized. The revenue was analyzed on two levels: total revenue acquired during the tax year and the amount of the annual $1 \%$ of personal income tax. The results of the study indicate that Web sites of analyzed organizations fail to fully implement the dialogic communication principles. The statistical correlation between the sum of annual revenue and $1 \%$ of personal income tax and the utilization of dialogic principles was partially supported. Nonprofits appeared to show their greatest strengths in providing basic information to online users, such as a mission statement, organization logo and history, short loading time, general contact information on the homepage and major links on the homepage to subpages. Organizational division into three clusters highlighted quite significant differences in the utilization of dialogic principles. The Web sites of the largest Polish PBOs in terms of total annual revenue and $1 \%$ of personal income tax are characterized by significantly higher dialogic communication potential.
\end{abstract}

Keywords: Non-Profit Management; Information Management; Internet; Website; Relationship Cultivation Strategies; Dialogic Communication.

\section{Introduction}

In the contemporary world, each type of organization is coping with the growing influence of competitors and consumers. This also applies to non-profit organizations which compete on the market for resources, especially those of a financial nature. Information technology is a useful tool in not only effectively mobilizing resources, but also facilitating the managers of those organizations to make decisions that identify the stakeholders and build positive relationships with them. Many scholars and practitioners believe that Public Relations is all about building and maintaining relationships with its public, building organizational effectiveness and contributing to its statutory objectives. The authors of Effective Public Relations (Cutlip, Center \& Broom, 1994) defined public relations as "the management function that establishes and maintains mutually beneficial relationships between an organization and the publics on whom its success or failure depends". Moreover, the relational perspective is consistent with the notion that public relations initiatives should generate understanding and benefit both for organizations and publics (Grunig \& Hunt, 1984; Ledingham \& Bruning, 2001). In that context communication is used as a strategic tool in helping to achieve those goals.

Since their first appearance in 2004, Polish Public Benefit Organizations (PBOs) have become a thriving

${ }^{1}$ http://www.pozytek.gov.pl/Wykaz,Organizacji,Pozytku,Publicznego,366 6.html component of the third sector. According to the Department of Social Economy and Public Benefit, in the list of PBOs as of January 31, 2017 more than 8.5 thousand organizations having the status of PBOs were registered ${ }^{1}$, and from 2004 to 2010 their total number increased by almost 4-fold, and then stabilized afterwards. Having the status of PBO is associated with the use of certain privileges; among them the most important is the right to receive $1 \%$ of personal income tax or the right to corporate income and property tax exemption $^{2}$. A key element in the daily activities of these types of organizations is continuous communication with different stakeholder groups, which ultimately may reward the PBO with higher financial revenues which will help in the implementation of organizational statutory objectives. Such a philosophy of Public Benefit Organization actions is deeply rooted in a system-based approach together with resource dependency and contingency theory, which also rest upon a systematic framework. (Pfeffer \& Salancik, 2003; O'Connor \& Netting, 2009). According to Resource Dependence Theory, the key to organizational growth is the ability to acquire resources. It acknowledges the crucial role that the environment has for the success of an organization. Resource dependency theory sees organizations as dependent upon their environment for scarce resources that ultimately help the organizations to survive and thrive. A 
resource is anything that is deemed valuable such as information, capital, or other materials. The results of studies of the non-profit sector in Poland (Central Statistical Office of Poland 2016) explicitly confirm the importance of these theories in the functioning of such organizations. The most important barriers indicated by Public Benefit Organizations were inadequate revenues from fundraising activities and an insufficient number of volunteers for community work. Certain economic features of PBOs (such as the right to receive $1 \%$ of personal income tax or the right to corporate income and property tax exemption) have not translated into a lower perception of the significance of these barriers. Therefore, fundraising has become a vital component of the day-to-day activities of charitable nonprofit organizations.

The Public Relations scholarly literature underlines the crucial role played by the relationship cultivation strategies in fundraising and communication activities ( $\mathrm{Ki}$ and Hon, 2006, 2007, 2009; Waters, 2008, 2009; Jo, 2006). Waters (2007) defined fundraising as the management of relationships between a non-profit organization and its donor public, entirely different from previous definitions in which fundraising is primarily understood as "the seeking of gifts from various sources as conducted by non-profit organizations". Evaluation of these relationships becomes crucial, because there is no doubt, that they must be positive. The relational approach is significant because it situates relationship building as the public relations bottom-line (Broom, Casey, and Ritchey, 1997). An important feature of relationship building is dialogic communication (Kent and Taylor, 1998). Kent and Taylor recommended five strategies that can be used for relationship cultivation which would aid in creating mediated, two-way, dialogic relationships with the public. For the first time, these strategies were applied to the analysis of online communication channels, at that time mainly Web sites. Kent and Taylor (1998) "argued that strategically designed Web sites and home pages may provide organizations with an opportunity to engage in dialogic relationships", although the mere use of these strategies (Hon \& Grunig, 1999) does not imply a dialogue with organization's stakeholders, but only an environment conducive to its creation. Further review of scholarly literature (e.g. Balser, McClusky, 2005; Theunissen, Wan Noordin, 2012; Uzunoglu, Kip, 2014) indicates that worldwide discussion about the dialogic communication theory have mostly been carried out in advanced economies, leaving developing countries out of the scientific mainstream, thus encouraging us to examine the dialogic potential of Polish largest Public Benefit Organizations. The native scientific literature in this area is very modest. There are only a few studies concerning the use of the Internet and the role of websites in building and maintaining relationships with its users in Poland (e.g. Domanski, 2008). This article is intended to fill this gap.

This research used the methodology originally developed by Kent and Taylor (1998), which during the implementation of the research process was modified to adapt to the current conditions of the non-profit organization. We have divided the categories regarding the usefulness of information in more detail and we have added new categories in the principle "generation of return visits"). Besides, in this principle new categories related to the use of social media services in the organization's activity have been added).

The technological advances of the late 1990s have also affected the non-profit sector, particularly in the area of communications. The advent and dynamic development of the Internet made it possible to reach organizational stakeholders at a relatively low cost without the need to carry out large advertising campaigns, which for the majority of small sized organizations would be difficult to overcome. The analysis of Web sites in terms of strategies employed to improve relationships with organizational stakeholders is not a new phenomenon in the scholarly literature. The main stream of research is now focusing on impact assessment, but most of all it is focused on various social media channels. Mainly, the organizational use of channels such as Facebook and Twitter is analyzed as part of an organization's diversity in terms of both size and type of business (e.g. Baumgarten, 2011; Bortree \& Seltzer 2009; Briones et al., 2011; Carboni \& Maxwell, 2015; Lovejoy, Saxton \& Waters, 2012; Rybalko \& Seltzer, 2010; Saxton \& Lovejoy, 2012; Waters et al., 2009). However, it should be remembered that this does not mean the depreciation of the Web site. It marks the organizational "business card". If we imagine the average Internet user, the potential donor to a specific non-profit organization, that person uses online search engines nearly every day. For example, if he or she needs information on a specific non-profit organization, the first contact will most likely take place through the Web site. Furthermore, to the non-profit authorities the Web site still remains the most important communication channel, as shown by the results of other research centres. Social networking sites like Facebook, Google Plus or microblogging like Twitter still occupy lower positions in that hierarchy ${ }^{3}$. Thus, the published content might play a crucial role while making a decision about providing support for a specific organization. Therefore, the authors of this article initially focused on the organizational use of Web 1.0 static tools - Web sites. At the same time, research is being carried out on the use of Web 2.0 tools like Facebook and Twitter. It concerns their use as a tool of stakeholder engagement.

The purpose of this article is to examine Public Benefit Organization Web sites to determine the extent to which they use dialogic communication rules in relationship building. In this study, an encoding scheme has been used based on the work of Taylor and Kent (1998) that has been modified for the needs of non-profit organizations. Taylor and Kent point out five strategies that can be used in relationship building with organization stakeholders via the organization Web site. These are the dialogic "loop" and the "generation of return visits", which are the features that directly form the dialogic potential of the organization Web site (Table 2); as well as the usefulness of information, ease of interface and conservation of visitors (Table 1). The last three are a group of technical features that are a prerequisite in building the site with a high dialogic communication

\footnotetext{
${ }^{3}$ http://www.nonprofitmarketingguide.com/blog/2016/01/05/the-2016 nonprofit-communications-trends-report-infographic/
} 
potential. In this group, the usefulness of the information plays an especially important role. The Web site should contain valuable information for different groups of stakeholders, especially for organizations competing for funds from the $1 \%$ of personal income tax. In the study, the stakeholders were divided into the following groups: general users, donors, volunteers and media (belonging to one group does not exclude belonging to the other ones). The dialogic loop principles concerns how the Web site includes features that let various members of the public question organizations. Significantly, it concerns how the Web site gives the organization the opportunity to reply to questions, concerns and claims. The dialogic loop refers to the two-way communication of the Web site and seems to be the most important principle in building a high dialogic potential, based on the key attribute of the Internet i.e. interactivity. In turn, the "generation of return visits" principles refers to how Web sites incorporate features that encourage recurring visits by making the site appealing. The "ease of interface" principle points out how convenient it is for Web users to browse a site. This technical principle is based on the assumption that stakeholders who visit a non-profit Web site should find it acceptably easy to navigate. Finally, the "conservation of visitors" principle includes important elements like the availability of important information on the homepage (latest news) to promote Web site traffic.

\section{The Methodology}

Firstly, in these studies we attempted to answer the following question: to what extent does the Web site of the largest Polish Public Benefit Organization include the elements which foster the creation of a "dialogic" environment. It has been claimed that dialogue is the most ethical form of public relations (Pearson, 1989). According to Ledingham \& Bruning (2000), the dialogic perspective "serves as a platform for developing public relations initiatives that generate benefit for organizations and for the publics they serve". In light of the new emphasis on "relationships" in public relations, "dialogue" appears to be one of the key features of the symmetrical model as an organizing principle in public relations theory building (Grunig, 1992; Day, Dong \& Robins, 2001). Public relations scholars have pointed out that both the business sector and non-profit organizations have been unable to fully exploit Web site potential. The results from other research centres indicate that the Web site mainly plays an informational role, and the possibilities offered by the Internet and the Web site in building dialogic potential are used only to a limited degree (Hinson, Van Zyl \& Agbleze, 2014; Ingenhoff \& Koelling, 2009; Kang \& Norton, 2004; Kenix, 2007; Madichie \& Hinson, 2014; Naude, Froneman \& Atwood, 2004; Uzunoglu $\&$ Kip, 2014). Thus, the first hypothesis posits that:

H1: The Web sites of the largest Polish Public Benefit Organizations are characterized by low dialogic potential, with an emphasis mainly on technical aspects.

Another issue analyzed in the study was the assessment of the relation between Web site dialogic potential and the amount of organization revenue. The revenue was analyzed on two levels: total revenue acquired during the tax year and the amount of the annual $1 \%$ of personal income tax. The Public Relations scholarly literature (Kang \& Norton, 2004; Ingehoff \& Koelling, 2007) indicates that the organizational use of the Internet in activities related to positive relationships with its stakeholders means that the gap between organizations with large budgets and organizations with lower annual revenues will not be as noticeable as it should be. Although, the mere fact of a larger budget at the organizations disposal usually means access to better-skilled personnel and more sophisticated technical expertise, which should translate into a higher dialogic potential of its Web site. Thus, the second hypothesis posits that:

H2: Organizations with greater total revenue will design a Web site with higher dialogic potential than those with lower revenue.

In the scholarly literature (Ingenhoff, 2009; Kent, 2003), a significant relationship between Internet utilization in Public Relations activities and an organizational dependence on stakeholders is mentioned. Therefore, it is likely that the degree of organizational dependence on donor contributions or on-line fundraising programmes has an impact on the construction of Web sites with higher dialogic potential. Since the authors did not have access to the data revealing the size of contributions from on-line donors, the main research was focused on the total amount of the $1 \%$ of personal income tax received by the non-profit organization. This data was available from the Department of Social Economy and Public Benefit Web site. Therefore, the third hypothesis posits that:

H3: A Web site with higher revenue from the $1 \%$ of personal income tax has a higher dialogic potential than organizations with a lower dependency on that source of revenue.

In the research, the purposive sampling method was used. The study included one hundred of the largest Polish Public Benefit Organizations in terms of total annual revenue and the total amount of $1 \%$ of personal income tax received in 2015, which was later divided into three clusters. The first cluster (number 1) included 73 organizations comprising the first hundred of the largest Polish Public Benefit Organizations in terms of the $1 \%$ of personal income tax received by the non-profit organization, but not falling within a group of 100 of the largest organizations in terms of total annual revenue. The second cluster (number 2) included 73 organizations comprising the first hundred of the largest Polish Public Benefit Organizations in terms of total annual revenue, but not falling within a group of 100 of the largest organizations in terms of the $1 \%$ personal income tax. The third cluster (number 3 ) included 27 organizations comprising both the largest organizations in terms of total annual revenue and the $1 \%$ personal income tax. Thus in total, the research involved 173 organizations. This figure eventually decreased to 169 , because one organization from the first cluster and three organizations from the second cluster did not maintain their own Web sites.

The financial data was obtained from a Public Benefit Organizations database located on the Department of Social Economy and Public Benefit Web site ${ }^{4}$. In accordance with

\footnotetext{
${ }^{4}$ www.pozytek.gov.pl
} 
article 23 paragraph 6 of the Public Benefit and Voluntary Service Act ${ }^{5}$, every Public Benefit Organization must submit financial statements and a technical report on its activities by the $15^{\text {th }}$ of July of the year following the year when the statements are submitted. It gives the opportunity to view valuable materials from the researcher's point of view, especially those of a financial nature. In the list of PBOs as of January 1, 2015, there were 8018 organizations. Since the publication date of the technical report for the year 2015 was later than 15 July 2016, the selection of organizations for testing couldn't begin until August 2016. It was a tedious and time-consuming process, firstly associated with the necessity of opening technical statements individually for each organization (there is no summary report available from the Department of Social Economy and Public Benefit Web site), secondly open pdf files were not editable, which meant the need to manually enter every single amount of revenue and the total value of the $1 \%$ of personal income tax. This part of the research process was completed in October 2016.

Differentiation among the 100 largest organizations in terms of annual revenue was substantial. The largest Polish organization in this regard was the Foundation for Children „Help on Time”. In 2015 it had at its disposal almost 17times higher revenue (over 178 million $\mathrm{zl}$ ) than the organization which ranked in the hundredth place i.e. the Christian Charity Association with less than 11 million $\mathrm{zl}$ of revenue. In 2015 only 13 organizations boasted revenue higher than 50 million zl. The average overall revenue for the 100 largest Polish Public Benefit Organizations was about 29.7 million $\mathrm{zl}$, the standard deviation reached 32.6 million and the median was 18.6 million zl. Differentiation among the 100 largest organizations in terms of the total value of the $1 \%$ of personal income tax was even bigger. Also in this case, the largest organization proved to be the Foundation for Children „Help on Time” with 136.8 million $\mathrm{zl}$ of total annual from that source. The second in that classification was the Charity Foundation for People with Special Needs "Słoneczko", which had more than 6-fold lower revenues from that source (20.8 million $\mathrm{zl})$. The lowest ranked Foundation was the "Parent Project Muscular Dystrophy", which did not even reach 1 million zl of annual income from the $1 \%$ of personal income tax. The average overall revenue from that source for the 100 largest Polish Public Benefit Organizations was about 3.0 million zl, the standard deviation reached 13.7 million and the median was 1.6 million $\mathrm{zl}$. In terms of the activity type among the 173 selected organizations, the organizations concerning persons with disabilities $(22.5 \%)$ and the protection and promotion of health $(22 \%)$ dominated.

A research questionnaire consisting of 56 questions on a dichotomous scale was used, where responses were coded as follows: the presence of a particular element was coded as 1 , and its absence as a 0 . Each cluster consisted of the following number of features: ease of interface -7 features, conservation of visitors -4 features, the usefulness of information for the general public, donors, volunteers and media $-9,5,5$ and 4 respectively, the generation of return visits -15 features and the dialogic "loop" -7 features.
At the beginning of the study, $10 \%$ of the non-profit organization Web sites were tested in order to check the reliability of the coders (two coders were responsible for the content analysis of all non-profit Web sites). Kappa Cohen factor was used for this purpose, which ranged from 0.75 to 1.00 (mean $=0.91$ ) for all elements used in the survey. Data was compiled with the use of the statistical program SPSS. The following statistical procedures were applied to describe them: analyses based on standard parameters, Kruskal-Wallis and Mann-Whitney test, chi-square statistics assessed the statistical significance of the variable relationships at 0.05 , and Cramer's V was reported to examine the relationship strength between content categories and organizational characteristics.

\section{Results}

The results of the research indicate a low dialogic potential of analyzed Web sites. The largest Polish Public Benefit Organizations fail to fully implement dialogic communication features. Therefore, the first hypothesis has been supported. On average, 21.56 features were identified on 169 surveyed organization Web sites $(\mathrm{M}=38.8 \%, \mathrm{SD}=6.50)$. In the case of technical principles, which are the prerequisites for dialogic communication, the average number reached 15.65 out of 34 potential features $(M=46.7 \%, S D=4.71)$. The most frequently identified features were those located in the "conservation of visitors" principle ( $M=65.2 \%$, table 1$)$. This principle included 4 items. The Web site of the largest Polish Public Benefit Organization on average scored 2.61 of these. In second place, there was a principle associated with the usefulness of information for the general public $(\mathrm{M}=59.8 \%$ (5.38), SD =1.54). The high number of features such as: organization logo, mission statement/ statute-book and financial reports are important indicators of a high level of institutionalization (table 1). The items comprising the other 4 principles were clearly identified less often. Polish Public Benefit Organizations favoured communicating to "everyone" or the "general public" rather than defining specific target audiences or core constituencies. In the entire group of technical principles, Web site features such as: organizational logo, major links on the homepage to the subpages, the availability of important information on the homepage (latest news), short loading time, and organizational history/ about us score highest. The division of the organization into three clusters highlighted some important differences, primarily relating to the items concerning the usefulness of information for donors and volunteers. The frequency data of Web site features such as: a "donate on-line" option, a specified link with information for donors, contact information for donors on the homepage, a "how to join" button for volunteers, a specified link with information and cooperation principles for volunteers was by far greater in the largest organizations in terms of the total annual revenue and the $1 \%$ of personal income tax (cluster 3 ); when comparing the 73 organizations comprising the first hundred of the largest Polish Public Benefit Organizations in terms of total annual revenue (cluster 2). There was a difference compared to cluster no. 1, but it was not as significant.

${ }^{5}$ Public Benefit and Volunteer Work Act (publication date 24 April 2003, Act of Law from 2014, item 873, no. 96). 
Occurrence of Technical Features in Building the Web Site Dialogic Potential

\begin{tabular}{|c|c|c|c|c|}
\hline \multirow{4}{*}{ Principle/Feature(Item) } & \multicolumn{4}{|c|}{ Technical features of the Web site } \\
\hline & Total & Cluster 1 & Cluster 2 & Cluster 3 \\
\hline & $(\mathrm{N}=169) *$ & $(\mathbf{N}=72)$ & $(\mathbf{N}=70)$ & $(\mathbf{N}=27)$ \\
\hline & \multicolumn{4}{|c|}{$\%$} \\
\hline \multicolumn{5}{|l|}{ EASE OF INTERFACE $(\mathrm{M}=36.8 \%(2.57), \mathrm{SD}=1.32, \mathrm{n}=169)$} \\
\hline Sitemap & 17.8 & 16.7 & 14.3 & 29.6 \\
\hline Major links on the homepage to the subpages & 98.8 & 97.2 & 100.0 & 100.0 \\
\hline Search engine box & 58.6 & 48.6 & 64.3 & 70.4 \\
\hline "Text" version only & 4.1 & 2.8 & 4.3 & 7.4 \\
\hline choice between low and high dependence on graphics & 14.2 & 6.9 & 20.0 & 18.5 \\
\hline Possibility to select language & 21.9 & 19.4 & 25.7 & 18.5 \\
\hline Links back to homepage & 42.0 & 34.7 & 51.4 & 37.0 \\
\hline \multicolumn{5}{|l|}{ CONSERVATION OF VISITORS $(\mathrm{M}=65.2 \%(2.61), \mathrm{SD}=0.17, \mathrm{n}=169)$} \\
\hline The availability of important information on the homepage (latest news) & 88.8 & 84.7 & 91.4 & 92.6 \\
\hline Specified date of last updated news publication & 71.0 & 61.1 & 75.7 & 85.2 \\
\hline Short loading time $(<4 \mathrm{sec})$. & 98.8 & 98.6 & 100.0 & 96.3 \\
\hline Presence of "splash screen" & 2.4 & 4.2 & 1.4 & 0.0 \\
\hline \multicolumn{5}{|c|}{$\begin{array}{l}\text { THE USEFULNESS OF INFORMATION FOR THE GENERAL PUBLIC } \\
(\mathrm{M}=59.8 \%(5.38), \mathrm{SD}=1.54, \mathrm{n}=169)\end{array}$} \\
\hline Organizational history/ About us & 91.1 & 93.1 & 85.7 & 100.0 \\
\hline Mission statement/ statute-book & 76.9 & 76.4 & 77.1 & 77.8 \\
\hline Organization logo & 100.0 & 100.0 & 100.0 & 100.0 \\
\hline Public Benefit Organization logo & 29.6 & 43.1 & 21.4 & 14.8 \\
\hline Financial reports & 79.9 & 83.3 & 72.9 & 88.9 \\
\hline Multimedia galleries & 78.1 & 79.2 & 75.7 & 81.5 \\
\hline Option of ,how to join” for new members of the organization & 9.5 & 5.6 & 7.1 & 25.9 \\
\hline Other organizational documentation & 51.5 & 43.1 & 51.4 & 74.1 \\
\hline News archive & 21.3 & 13.9 & 27.1 & 25.9 \\
\hline \multicolumn{5}{|c|}{$\begin{array}{l}\text { THE USEFULNESS OF INFORMATION FOR DONORS (M=38.1\% (1.91), SD } \\
=1.37, \mathrm{~N}=169)\end{array}$} \\
\hline How to contribute money on homepage or separated link & 81.7 & 91.7 & 70.0 & 85.2 \\
\hline Contact information for donors on the homepage & 17.8 & 13.9 & 11.4 & 44.4 \\
\hline "Donate on-line" option & 49.1 & 68.1 & 20.0 & 74.1 \\
\hline Information on how the donated money is used & 16.0 & 18.1 & 8.6 & 29.6 \\
\hline Specified link with information for donors & 26.0 & 27.8 & 12.9 & 55.6 \\
\hline \multicolumn{5}{|c|}{$\begin{array}{l}\text { THE USEFULNESS OF INFORMATION FOR VOLUNTEERING }(\mathrm{M}=36.1 \% \\
(1.81), \mathrm{SD}=1.89, \mathrm{~N}=149)\end{array}$} \\
\hline "How to join" button & 33.1 & 41.7 & 12.9 & 48.1 \\
\hline Contact information for the volunteer on the homepage & 48.3 & 48.6 & 37.1 & 48.1 \\
\hline Specified link with information for volunteers & 49.0 & 61.1 & 27.1 & 51.9 \\
\hline Description of cooperation principles & 22.8 & 23.6 & 10.0 & 40.7 \\
\hline Clearly visible call to action & 27.6 & 26.4 & 20.0 & 33.3 \\
\hline \multicolumn{5}{|c|}{$\begin{array}{l}\text { THE USEFULNESS OF INFORMATION FOR MEDIA }(\mathrm{M}=38.3 \%(1.53) \text {, SD } \\
=1.11, n=169)\end{array}$} \\
\hline Specified link with information for the media & 21.3 & 15.3 & 22.9 & 33.3 \\
\hline Clearly stated positions/speeches & 17.2 & 9.7 & 21.4 & 25.9 \\
\hline Biographical note about organization authorities & 81.1 & 79.2 & 82.9 & 81.5 \\
\hline Press releases & 33.7 & 31.9 & 30.0 & 48.1 \\
\hline
\end{tabular}

* The number of organizations eventually decreased from 173 to 169 , because one organization from the first cluster and three organizations from the second cluster did not maintain their own Web sites. Source: own study

In comparison to technical features of dialogic communication, the principles directly creating the dialogic potential were clearly identified less frequently. On average, the Web sites of 169 analyzed organizations scored 5.91 features out of potentially 22 in total $(26.9 \%, \mathrm{SD}=2.47)$, comprising the dialogic "loop" and the generation of return visits principle. All dialogic "loop" indices (except for general contact information on homepage) scored less than $30 \%$. Table number 2 clearly indicates that the analyzed Web sites only incidentally exploited the interactive possibilities of the Internet (e.g. opportunity for user response, chatroom or opportunities to vote on issues), rather focusing on the information dissemination role of Web sites (general contact information on homepage or links to other websites). Almost $80 \%$ of organizations have a Facebook button on the organization website (92.6 organizations in cluster 3 ) and possibly its interactive nature is better utilized by organizations, leaving the Web site to have a mainly informational role. The division of the organization into three clusters did not change much in this area, except the newsletter subscription and the use of the Twitter feature which in organizations from cluster 3 were identified much more often in comparison to organizations from cluster 1 and especially cluster 2 . One of the most important features in the dialogic "loop" principle is the opportunity for a user response and the organization responding to on-line user comments. This was more common in cluster 3 organizations, but was still at a low level (14.8\% in both cases). 
Occurrence of Dialogic Features Directly Fostering Dialogue

\begin{tabular}{|c|c|c|c|c|}
\hline \multirow{4}{*}{ Principle/Feature } & \multicolumn{4}{|c|}{ Dialogic features of the Web site } \\
\hline & Total & Cluster 1 & Cluster 2 & Cluster 3 \\
\hline & $(\mathrm{N}=169)$ & $(\mathrm{N}=72)$ & $(\mathrm{N}=70)$ & $(\mathrm{N}=\mathbf{2 7})$ \\
\hline & \multicolumn{4}{|c|}{$\%$} \\
\hline \multicolumn{5}{|l|}{ DIALOGIC „LOOP” (M=23,9\% (1.67), SD =0.94, N=169) } \\
\hline Opportunity for user response & 7.1 & 6.9 & 4.3 & 14.8 \\
\hline The organization responds to on-line users comments & 5.3 & 5.6 & 1.4 & 14.8 \\
\hline Opportunities to vote on issues & 2.4 & 2.8 & 1.4 & 3.7 \\
\hline On-line surveys to voice opinions on issues, competitions & 17.8 & 9.7 & 24.3 & 22.2 \\
\hline Newsletter subscription & 27.2 & 23.6 & 22.9 & 48.1 \\
\hline Blogs/video blogs & 9.5 & 12.6 & 4.3 & 14.8 \\
\hline General contact information on homepage & 98.2 & 97.2 & 98.6 & 100.0 \\
\hline \multicolumn{5}{|c|}{ GENERATION OF RETURN VISITS (M=28.2\% (4.24), SD =1.93, N=169) } \\
\hline Forum & 7.7 & 8.3 & 5.7 & 11.1 \\
\hline FAQ & 15.4 & 18.1 & 10.0 & 22.2 \\
\hline Bookmark now & 1.2 & 2.8 & 0.0 & 0.0 \\
\hline Links to other websites & 78.1 & 80.6 & 74.3 & 81.5 \\
\hline Calendar of events & 10.7 & 5.6 & 15.7 & 11.1 \\
\hline Downloadable files (audio/video, pdf, etc.) & 58.0 & 54.2 & 57.1 & 70.4 \\
\hline Providing information on request, e.g. via e-mail & 36.1 & 40.3 & 35.7 & 25.9 \\
\hline Posting new stories at least every 30 days & 72.2 & 62.6 & 80.0 & 77.8 \\
\hline Podcasts & 1.2 & 2.8 & 0.0 & 0.0 \\
\hline RSS & 7.7 & 2.8 & 11.4 & 11.1 \\
\hline Chatroom & 1.8 & 2.8 & 1.4 & 0.0 \\
\hline The option to register as a permanent Web site user & 17.8 & 15.3 & 15.7 & 29.6 \\
\hline Facebook button on organization website & 79.9 & 81.9 & 72.9 & 92.6 \\
\hline Twitter button & 20.7 & 22.2 & 12.9 & 37.0 \\
\hline Online store & 15.4 & 16.7 & 11.4 & 22.2 \\
\hline
\end{tabular}

Source: own study

Dividing organizations into three clusters (table 3) highlighted quite significant differences in the utilization of dialogic principles, especially if we compare the organizations from cluster no. 2 - the largest in terms of total annual revenue $(\mathrm{N}=70)$ and from cluster 3 - the largest both in terms of total annual revenue and the $1 \%$ of personal income tax $(\mathrm{N}=27)$. On average, the third cluster scored highest for all 56 dialogic principles $(\mathrm{M}=25.55)$ in comparison to organizations from cluster no. 1 and 2 ( $M=21.56$ and 20.16 respectively). The biggest differences were observed in the usefulness of information principles both in general and at a specific level, but were much smaller when compared to organizations in cluster no. 1 . The Kruskal-Wallis test $\left(\chi^{2}(2)=10.287, p=0.006\right)$ indicates that a statistically significant correlation exists between the three compared clusters (the average rank for cluster no. $1=$ 75.75 ; the average rank for cluster no. $2=84.17$; the average rank for cluster no. $3=111.19)$. In addition, the MannWhitney tests were carried out in order to precisely determine between which clusters statistical differences occurred. These results indicated that there is a statistically significant difference between the third and the first cluster
( $U=662,50, Z=-2,436, p=0,015)$ and between third and second cluster $(U=547,50, Z=-3,204, p=0,001)$. The Web sites of the largest Polish Public Benefit Organizations in terms of total annual revenue and the $1 \%$ of personal income tax are characterized by significantly higher dialogic communication potential than those organizations which are part of the cluster with only the largest total annual revenue or the cluster with only the largest part of the $1 \%$ of personal income tax. 
A Summary of the Technical and Dialogic Features of Public Benefit Organization Web sites

\begin{tabular}{|c|c|c|c|c|c|c|c|c|c|}
\hline \multirow{2}{*}{ The dialogic principles } & \multicolumn{3}{|c|}{ Cluster $1(n=72)$} & \multicolumn{3}{|c|}{ Cluster 2(n=70) } & \multicolumn{3}{|c|}{ Cluster $(n=27)$} \\
\hline & $\mathrm{M}$ & $\mathrm{SD}$ & $\%$ & $\mathrm{M}$ & SD & $\%$ & $\mathrm{M}$ & $\mathrm{SD}$ & $\%$ \\
\hline Ease of interface $(7)^{*}$ & 2.26 & 1.20 & 32.3 & 2.80 & 1.30 & 40.0 & 2.81 & 1.47 & 40.2 \\
\hline Conservation of visitors (4) & 2.51 & 0.18 & 62.9 & 2.69 & 0.15 & 67.1 & 2.74 & 0.15 & 68.5 \\
\hline $\begin{array}{l}\text { The usefulness of information for the general } \\
\text { public (9) }\end{array}$ & 5.38 & 1.41 & 59.7 & 5.19 & 1.68 & 57.6 & 5.89 & 1.40 & 65.4 \\
\hline The usefulness of information for donors (5) & 2.20 & 1.13 & 43.9 & 1.23 & 1.14 & 24.6 & 2.89 & 1.64 & 57.8 \\
\hline The usefulness of information for volunteers (5) & 2.20 & 1.80 & 43.9 & 1.13 & 1.65 & 22.7 & 2.22 & 2.16 & 44.4 \\
\hline The usefulness of information for media (4) & 1.36 & 1.05 & 34.0 & 1.57 & 1.41 & 39.3 & 1.89 & 1.09 & 47.2 \\
\hline $\begin{array}{l}\text { Total number of technical principles features } \\
\text { (34) }\end{array}$ & 15.69 & 4.50 & 46.8 & 14.54 & 4.40 & 43.4 & 18.44 & 4.9 & 54.3 \\
\hline Dialogic ,loop” (7) & 1.58 & 0.97 & 22.6 & 1.57 & 0.73 & 22.5 & 2.15 & 1.18 & 30.7 \\
\hline The generation of return visits (15) & 4.17 & 1.91 & 27.8 & 4.04 & 2.07 & 27.0 & 4.93 & 1.41 & 32.8 \\
\hline $\begin{array}{l}\text { Total number of directly dialogic principle } \\
\text { features (22) }\end{array}$ & 5.75 & 2.41 & 26.1 & 5.61 & 2.50 & 25.5 & 7.11 & 2.17 & 32.2 \\
\hline Total for all analyzed features $(56)$ & 21.44 & 6.34 & 38.6 & 20.16 & 6.10 & 36.3 & 25.55 & 6.29 & 45.6 \\
\hline
\end{tabular}

* The number of features comprising the single principle. Source: own study

The second hypothesis posits the existence of a statistically significant relation between the total annual revenue and Web site dialogic potential. Revenues were divided into three sized groups, i.e. over 20 million zl; from 10 million to 20 million $\mathrm{zl}$; or below 10 million $\mathrm{zl}$ (data from annual reporting forms). The Polish Public Benefit Organization operating system does not have explicitly defined boundaries separating small, medium and large nonprofit organizations. The study included the largest Polish Public Benefit Organizations, but due to large discrepancies in the total amount of annual revenue, the division employed is intended to establish three comparable groups. Analyzing all the elements creating the dialogical potential of a website, it should be emphasized that there is no statistical relationship between this potential and the total revenue of the organization.
PBOs with higher revenue tend to create Web sites with a higher dialogic potential than organizations with lower revenues (Table 3), only in the case of two dialogic principles both comprising the technical and design ones. The chi-square independence test indicated that a statistically significant correlation exists for the usefulness of the information for donors $(\chi 2(4, \mathrm{~N}=173)=26.91, \mathrm{p}<.001)$ and volunteers - in the reporting year 2015 among the 173 surveyed organizations, 149 organizations used the work of volunteers $(\chi 2(8, \mathrm{~N}=149)=14.21, \mathrm{p}=.006)$, although its strength is quite modest (Cramer's V .278, .218 respectively). Organizations with the highest annual revenue attach an especially important role to these features of the Web site, which include elements relevant to potential donors and volunteers. Therefore, hypothesis number 2 was rejected.

Table 4

The Value of the Chi-Square Statistic in the Independence test of Selected Indicators with Designated Coefficients (Cramer's V)

\begin{tabular}{|c|c|c|c|c|}
\hline Selected elements describing the companies under study & $\chi^{2}$ & $d f$ & p-value & Cramer's $V$ \\
\hline \multicolumn{5}{|c|}{ Amount of revenue } \\
\hline Ease of interface & 7.730 & 4 & 0.101 & - \\
\hline Conservation of visitors & 3.430 & 2 & 0.180 & - \\
\hline The usefulness of information for the general public & 6.165 & 4 & 0.187 & - \\
\hline The usefulness of information for donors & 26.908 & 4 & $<0.001$ & 0.278 \\
\hline The usefulness of information for volunteers & 14.214 & 4 & 0.006 & 0.218 \\
\hline The usefulness of information for media & 3.596 & 2 & 0.165 & - \\
\hline Dialogic „loop” & 4.274 & 4 & 0.370 & - \\
\hline The generation of return visits & 2.188 & 4 & 0.701 & - \\
\hline Total number of dialogic principle features & 10.672 & 8 & 0.220 & - \\
\hline
\end{tabular}

Source: own study

The third hypothesis was to determine whether the source of revenue had an impact on the dialogic potential of Public Benefit Organization Web sites. Public Benefit Organizations might generate revenue from a variety of sources, which in the Polish legal system are divided into gratuitous public benefit activities (free of charge services for beneficiaries), "business" revenues which consist of revenues from business activities, paid public benefit activities for beneficiaries (although the beneficiary payment service covers only the costs without profit for the organization) and the $1 \%$ of personal income tax. From a research point of view, the last source seems to be the most relevant. A possibility to receive $1 \%$ of personal income tax represents one of the most important features of the Public Benefit Organization. For the year 2015, personal income taxpayers who applied for $1 \%$ of their personal income tax to be transferred to a Public Benefit Organization donated on average $47 \mathrm{zl}$ (13.2 M. individual taxpayers in Poland). Every year the quantity of this revenue gradually increases. Since 2010, more than a $20 \%$ increase in the total sum of donations has been recorded, and the number of taxpayers transferring $1 \%$ of their personal income tax increased by 
$31 \%$. So, by cultivating relationships based on dialogue, the Web site should encourage the user to make a donation. Therefore, the relationship between the $1 \%$ of tax income from individuals and the Web site dialogic potential was also examined. The results indicate that a statistically significant correlation exists between the $1 \%$ of personal income tax and three dialogic principles. As in the case of the total annual revenue, the relevance was identified in the case of the usefulness of information for donors $(\chi 2(6, N=173)$ $=40.942, \mathrm{p}<.001$, table 5$)$ and volunteers $(\chi 2(6, \mathrm{~N}=149)$ $=18.00, \mathrm{p}=.006)$. The strength of this statistical correlation was moderate (Cramer's V .344, .246 respectively). Additionally, results indicate that a positive and modest correlation exists between the $1 \%$ of tax revenue and the "generation of return visits" $(\chi 2(6, \mathrm{~N}=173)=22.17, \mathrm{p}=.001)$, as well as in the case of the total number of dialogic principles features $(\chi 2(6, \quad \mathrm{~N}=173)=29.699, \mathrm{p}=.003)$. Therefore, the third hypothesis was supported. However, higher total organizational revenues and higher $1 \%$ of personal income tax does not translate into the existence of a statistical relationship between the most important dialogic principles i.e. the dialogic "loop". A statistically significant correlation between $1 \%$ of personal income tax and the dialogic "loop" was observed until organizations were divided into 5 categories (organizations whose share of revenue from that source ranged from 75 to $100 \%$, from 50 to $75 \%$, from 25 to $50 \%$, from 10 to $25 \%$ and less than 10 $\%)$, but its strength measured by the contingency coefficient (Cramer's V) was weak $((\chi 2(8, \mathrm{~N}=173)=18.30, \mathrm{p}=.019$, Cramer's V .155). Also in this scenario, a statistically significant correlation exists in the case of the usefulness of information for donors $(\chi 2(8, \mathrm{~N}=173)=28.25, \mathrm{p}<.001)$, volunteers $(\chi 2(8, \mathrm{~N}=149)=24.60, \mathrm{p}<.001)$, and ease of interface $(\chi 2(8, \mathrm{~N}=173)=15.87, \mathrm{p}=.044)$ principle, although in all three instances, the strength was moderate at best (Cramer's V .286, .287, .214 respectively).

Table 5

The Value of the Chi-Square Statistic in the Independence Test of Selected Indicators with Designated Coefficients (Cramer's V)

\begin{tabular}{|c|c|c|c|c|}
\hline Selected elements describing the companies under study & $\chi^{2}$ & $d f$ & p-value & Cramer's $V$ \\
\hline \multicolumn{5}{|c|}{$1 \%$ of personal income tax } \\
\hline Ease of interface & 3.449 & 6 & 0.751 & - \\
\hline Conservation of visitors & 6.022 & 3 & 0.110 & - \\
\hline The usefulness of information for the general public & 11.084 & 6 & 0.0856 & - \\
\hline The usefulness of information for donors & 40.942 & 6 & $<0.001$ & 0.344 \\
\hline The usefulness of information for volunteers & 18.002 & 6 & 0.006 & 0.246 \\
\hline The usefulness of information for media & 0.7921 & 3 & 0.851 & - \\
\hline Dialogic „loop” & 3.158 & 6 & 0.789 & - \\
\hline The generation of return visits & 22.173 & 6 & 0.001 & 0.253 \\
\hline Total number of dialogic principle features & 29.699 & 12 & 0.003 & 0.239 \\
\hline
\end{tabular}

Source: own study

\section{Conclusions}

In the PR scholarly literature, dialogic communication has been portrayed as one of the most useful conceptualizing tools for explaining the organization-public relationship. In turn, the Web site has been described as one of the most vital communication tools for non-profit organizations. Combining these two perspectives, this research has provided insight into the utilization of the Web site for dialogic objectives. However, the results of these studies do not confirm these viewpoints. The largest Polish Public Benefit Organizations are characterized as having low dialogic communication potential; especially in the areas of the dialogic "loop" and the "generation of return visits" principles, which are considered to be the most important. Web site features which would testify to a site's high interactivity and responsiveness (e.g. opportunity for user response) were used only marginally. Non-profits appeared to show their greatest strengths in providing basic information to online users, such as a mission statement, organization logo and history, general contact information on the homepage and major links on the homepage to the subpages, as well as having a short loading time. The results indicate a statistically significant correlation between the financial situation of the PBOs and the Web site dialogic potential in the usefulness of information for donors and volunteers principle. In the case of a large share of the $1 \%$ of personal income tax in total annual revenue, a correlation was also observed in the "generation of return visits" principle and in all 56 analyzed features, which is even more important. This contradicts the conjecture of Kang and Norton (2004) that the Internet could be utilized as a potential equalizer for public relations outcomes among organizations with differentiated budgets. Typically, the low budget of such organizations means that reaching a vast audience with specific organizational values and ideas seems to be a particularly difficult task. An organization's Web site appears to be an effective tool for achieving that goal, especially when the availability of cheap and simple designing Web site platforms is currently very common (e.g. Content Management System based on Wordpress).

Dividing organizations into three clusters highlighted quite significant differences in the Web site dialogic communication potential. The largest Polish PBOs in the case of $1 \%$ of personal income tax and total annual revenue was characterized by a clearly higher presence of these features which comprise the principle of usefulness of information both in general and at a specific level. It transfers into the higher Web site dialogic potential as a whole, especially compared to the organizations belonging to the second cluster, the largest in total annual revenue. These are the organizations which were characterized by a

\footnotetext{
${ }^{6}$ http://www.finanse.mf.gov.pl/pl/pit/statystyki
} 
significantly smaller share of the $1 \%$ of personal income tax in total annual revenue; more than half of them obtained less than 100 thousand $\mathrm{zl}$ revenue from that source. Therefore, the financing of these organizations is based primarily on public funds and has a low dependency on individual donors $^{7}$. To a large extent, it translates into the nature of organizational Web sites, which serve only as a digital information leaflet.

It should be emphasized that the research only provided an answer to the question whether there is a statistical relationship between the level of total revenues and the level of revenues from $1 \%$ of personal income tax, and the dialogue potential of the website. However, it is difficult to assess whether the higher dialogue potential of a website translates into a larger income from $1 \%$ of personal income tax or vice versa. Further research is needed in this area. Besides, this type of study is needed because there may be other factors that affect the website's dialogical potential. For example, it may be the employment rate and the qualifications of the staff, or the geographical scope of the organization's activities.

It is worth mentioning that the third cluster organizations were characterized by a high level of standard deviation values in the usefulness of information for donors and volunteers principle (table 3 ). On the one hand, we are dealing with organizations capable of creating a Web site full of features comprising these two dialogic principles, and on the other hand, organizations with a much smaller share of it. For instance, the Web site of 11 organizations from the third cluster were characterized as having a high share of information specific for donors, the Web site of 9 organizations as having a high share of information specific for volunteers, and the commonalities represented just 4 organizations. Therefore, only for those organizations is it possible to apply the rule: defining a specific target audience or core constituency, rather than communicating to "everyone" or the general public. This is significant, especially when the on-line donation option on the Web site has become a standard. Therefore, the Web site should correspond to the specific needs of potential on-line donors and volunteers. Only a few major Polish Public Benefit Organizations meet these conditions.

While we believe our findings and recommendations are important for the Polish PBO sector, we acknowledge the study's limitations. While some authors might argue that Kent and Taylor's (1998) method is a bit outdated, we posit that it is a solid foundation for future studies; especially in the area of social networking sites. The Web site remains the most popular landing page for the users of most common search engines, since it is a platform from which you can get further access to social media channels. Therefore, there is a necessity for further research in the utilization of social networking sites by Public Benefit Organizations, especially the most popular one - Facebook. The results indicate that almost $80 \%$ of analyzed Web sites placed a Facebook button on their Web site. By comparing these two channels - the Web site on the one hand and Facebook on the other, we can get the answer to why the Web sites of the largest Polish Public Benefit Organizations act predominantly as digital information leaflets; and if Facebook (with its highly integrated interactivity) is the main location where the organizations build relationships with the public based on dialogue.

\section{References}

Balser, D., \& McClusky, J. (2005). Managing stakeholder relationships and nonprofit organization effectiveness. Nonprofit Management and Leadership, 15 (3). https://doi.org/10.1002/nml.70

Baumgarten, C. (2011). Chirping for Charity: How U.S. Nonprofit Organizations Are Using Twitter to Foster Dialogic Communication. The Elon Journal of Undergraduate Research in Communications, 2.

Bortree, D. S., \& Seltzer, T. (2009). Dialogic strategies and outcomes: an analysis of environmental advocacy groups' Facebook profiles. Public Relations Review, 35. https://doi.org/10.1016/j.pubrev.2009.05.002

Briones. R. L., Kuch, B., Fisher Liu, B., \& Jin, Y. (2011). Keeping up with the digital age: How the American Red Cross uses social media to build relationship. Public Relations Review, 37. https://doi.org/10.1016/j.pubrev.2010.12.006

Broom, G. M., Casey, S., \& Ritchey, J. (1997). Toward a concept and theory of organization-public relationships. Journal of Public Relations Research, 9(2). https://doi.org/10.1207/s1532754xjprr0902_01

Carboni, J. L., \& Maxwell, S. P. (2015). Effective Social Media Engagement for Nonprofits: What Matters? Journal of Nonprofit and Public Affairs, 1.

Cutlip, S. M., Center, A. H., \& Broom, G. M. (1994). Effective public relations (7th ed.), Englewood Cliffs, Prentice- Hall, NJ

Day, K. D., Dong, Q., \& Robins, C. (2001). Public relations ethics: an overview and discussion of issues for the 21st century, in: R.L. Heath (Ed.), Handbook of Public Relations, Sage Publications. Thousand Oaks, CA. https://doi.org/10.4135/9781452220727.n32

\footnotetext{
7 According to financial statements of analyzed PBOs -

http://www.ekonomiaspoleczna.gov.pl/
} 
Domanski J. (2008). Internet w działalności organizacji nonprofit, in: R. Knosala (Ed.), Komputerowo Zintegrowane Zarzadzanie, Oficyna Wydawnicza Polskiego Towarzystwa Zarzadzania Produkcja, Opole.

Grunig, J. E., \& Hunt, T. (1984). Managing public relations, Holt, Rinehart \& Winston, New York

Grunig, J. E. (1992). Excellence in Public Relations and Communication Management, Lawrence Erlbaum Associates. Hillsdale, NJ.

Hinson, R. E., \& Van Zyl, H., Agbleze, S. (2014). An interrogation of the dialogic potential of insurance firm websites in Ghana. Information Development, 30. https://doi.org/10.1177/0266666913477879

Hon, L. C., \& Grunig, J. E. (1999). Guidelines for measuring relationships in public relations. Gainesville, FL: Institution for Public Relations.

Ingenhoff, D., \& Koelling, A. M. (2009). The potential of Web sites as a relationship building tool for charitable fundraising NPOs. Public Relations Review, 35. https://doi.org/10.1016/j.pubrev.2008.09.023

Jo, S. (2006). Measurement of organization- public relationships: Validation of measurement using a manufacturer- retailer relationship. Journal of Public Relations Research, 18 (3). https://doi.org/10.1207/s1532754xjprr1803_2

Kang, S., \& Norton, H. E. (2004). Nonprofit organizations' use of the World Wide Web: are they sufficiently fulfilling organizational goals? Public Relations Review, 30. https://doi.org/10.1016/j.pubrev.2004.04.002

Kenix, L. J. (2007). In search of utopia: an analysis of nonprofit web pages. Information, Communication \& Society, 10.

Kent, M. L., \& Taylor, M. (1998). Building dialogic relationships through the World Wide Web. Public Relations Review, 24. https://doi.org/10.1016/S0363-8111(99)80143-X

Ki E. J., \& Hon L. C. (2006). Relationship maintenance strategies on Fortune 500 company Web sites. Journal of Communication Management, 10.

Ki, E. J., \& Hon, L. C. (2007). Testing the linkages among the organization-public relationship and attitude and behavioral intentions. Journal of Public Relations Research, 19(1).

Ki E. J., \& Hon, L. C. (2009). A Measure of Relationship Cultivation Strategies. Journal of Public Relations Research, 21(1).

Ledingham, J. A., \& Bruning, S. D. (2000). Public Relations as Relationship Management: A Relational Approach to the Study and Practice of Public Relations, Lawrence Erlbaum Associates, Hillsdale, NJ.

Ledingham, J. A., \& Bruning, S. D. (2001). Community relations. in: R.L. Heath (Ed.), Handbook of Public Relations, Sage Publications. Thousand Oaks, CA.

Lovejoy, K., Waters R. D., \& Saxton G. D. (2012). Engaging stakeholders through Twitter: How non-profit organizations are getting more out of 140 characters or less. Public Relations Review, 38. https://doi.org/10.1016/j.pubrev.2012.01.005

Madichie, N. O., \& Hinson, R. (2014). A critical analysis of the "dialogic communication" potential of sub-Saharan African Police Service websites. Public Relations Review, 40. https://doi.org/10.1016/j.pubrev.2013.10.009

Naude, A. M. E., Froneman, J. D., \& Atwood, R. A. (2004). The use of the Internet by ten South African non-governmental organizations - $\mathrm{a}$ public relations perspective. Public Relations Review, 30. https://doi.org/10.1016/j.pubrev.2003.11.008

O'Connor, M. K., \& Netting, F. E. (2009). Organization practice: A social worker's guide to understanding human services, John Wiley \& Sons Inc., Hoboken, NJ.

Pearson, R. (1989). Business ethics as communication ethics: public relations practice and the idea of dialogue, in: C.H. Botan, Vincent Hazleton (Eds.). Public Relations Theory, Lawrence Erlbaum and Associates, Hillsdale, NJ.

Pfeffer, J., \& Salancik, G. R. (2003). The external control of organizations: A resource dependency perspective. Harper \& Row Publishers Inc., New York.

Rybalko, S., \& Seltzer, T. (2010). Dialogic communication in 140 characters or less: How Fortune 500 companies engage stakeholders using Twitter. Public Relations Review, 36. https://doi.org/10.1016/j.pubrev.2010.08.004 
Theunissen P., \& Wan Noordin W. N. (2012). Revisiting the concept "dialogue" in public relations. Public Relations Review, 38(1). https://doi.org/10.1016/j.pubrev.2011.09.006

Uzunoglu, E., \& Kip, S. M. (2014). Building relationships through websites: A content analysis of Turkish environmental non-profit organization's (NPO) websites. Public Relations Review, 40. https://doi.org/10.1016/j.pubrev.2013.06.001

Waters, R. D. (2007). Nonprofit Organizations' Use of the Internet A Content Analysis of Communication Trends on the Internet Sites of the Philanthropy 400. Nonprofit Management \& Leadership, vol. 18, no. 1, https://doi.org/10.1002/nml.171

Waters, R. D. (2008). Applying relationship management theory to the fundraising process for individual donors. Journal of Communication Management, 12(1). https://doi.org/10.1108/13632540810854244

Waters, R. D., Burnett E., Lamm A., \& Lucas J. (2009). Engaging Stakeholders through Social Networking: How Nonprofit Organizations Are Using Facebook. Public Relations Review, 35. https://doi.org/10.1016/j.pubrev.2009.01.006

Waters, R. D. (2009). The Importance of Understanding Donor Preference and Relationship Cultivation Strategies. Journal of Nonprofit \& Public Sector Marketing, 9. https://doi.org/10.1080/10495140802662523

The article has been reviewed. Received in April, 2017; accepted in May, 2018. 